\title{
AN ATTEMPT TO ASSESS THE SCALE OF HIDDEN UNEMPLOYMENT IN POLISH AGRICULTURE IN 2017
}

\author{
Włodzimierz Kołodziejczak ${ }^{\bowtie}$
}

Poznań University of Life Sciences, Poland

\begin{abstract}
Hidden employment in agriculture is one of the key outstanding problems in the Polish rural modernization process. The purpose of this paper is to estimate the extent of changes in the Polish market in a scenario where the share of agricultural employees in the total number of employees would be close to that recorded in European Union countries (5\%). In the study period, the level of hidden unemployment in agriculture varies from one voivodeship to another. The level of agricultural employment and the amount of surplus workforce suggest that structural factors continue to have a strong impact. There are no realistic ways to reduce agricultural employment if the released workforce have no alternative non-agricultural job opportunities which are conveniently located and match their qualitative characteristics. However, the $5 \%$ level used in the simulation seems attainable within a ten to twenty-year time frame, mainly because of the persistent economic growth and a shortage of labor experienced in non-agricultural sectors. The creation of jobs and the alignment of qualitative (structural) characteristics between labor supply and demand must be a natural process resulting in a sustainable balance in the labor market which does not require to be artificially maintained with public funds.
\end{abstract}

Keywords: hidden unemployment, agrarian unemployment, surplus employment, farming population, labor market, employment, rural areas

\section{INTRODUCTION}

It is hard to overestimate the importance of individual farming as the place of work and livelihood, especially for the rural population. For decades, individual farms have been the basic guarantee of national food security and a safe haven for private ownership found nowhere else in the former socialist bloc. Because of the economic transformation, the subsequent evolution of economic conditions of farming, and the resulting transformation of the agriculture's institutional and social environment, individual farms faced the need to adapt to new conditions. Unfortunately, these new conditions (primarily including market factors) transformed into threats to the economic existence of some of them. The traditional Polish model of individual farming, characterized by land fragmentation and by small farms who often lack specialization of production and use large amounts of labor, proved to be economically inefficient and failed to provide the farming population with incomes comparable to those earned in non-agricultural sectors (Polska wieś, 2018).

Poland is among the countries where labor productivity in agriculture is relatively low compared to other sectors. The recent increase in farming incomes is not related to an improvement in labor productivity but rather to the global rise in prices of agricultural commodity and to direct payments obtained since Poland's accession to the European Union (Floriańczyk, 2009; Strzelecki, 2010). Rembisz (2016) claims that remunerations in the agriculture sector are much higher than labor productivity while it is the opposite for other sectors. The reasons could be the excessive employment in the Polish agriculture sector (which reduces labor

$\bowtie$ PhD Włodzimierz Kołodziejczak, Department of Finance and Accounting, Poznań University of Life Sciences, Wojska Polskiego 28 St., 60-637 Poznań, Poland, e-mail: kolodziejczak@up.poznan.pl; https://orcid.org/0000-0001-7315-6717 
productivity) and the fact that the remunerations of agricultural employees include transfers made under the CAP (which increase the wages). The average employment figures for the Polish agriculture are much higher than in more economically developed Western European countries. In 2017, the average share of agricultural employees in the total population employed in the national economy in Poland was $10.2 \%$, compared to an average of $4.8 \%$ in the European Union (EUROSTAT, 2018). Therefore, to reach the Western European level of labor productivity and agricultural income, agricultural employment should be reduced to a level specific to these countries ${ }^{1}$

There are many reasons for making this assumption. However, when discussing the reduction of agricultural employment, it should be noted that agriculture continues to provide a buffer for those unable to effectively compete in the non-agricultural labor market ${ }^{2}$. There-

${ }^{1}$ For the purposes of this study, a less strict (but more realistic) scenario was used, i.e. the EU-27 average level. The author believes that the proposed method for improving agricultural labour productivity by partially releasing the workforce to nonagricultural sectors does not contradict the paradigm of sustainable agricultural development in a Pareto sense, as described by Czyżewski (2012); instead, it only indicates that the commitment to socio-economic sustainability of rural areas needs to be properly understood. Agricultural sustainability should not be opposed to labour efficiency (which is obvious when increasing the farms' turnover with transfers) but must be based on sound structural foundations. Only the commitment to seek a natural equilibrium of the system may provide long-lasting results. In turn, establishing a fake socio-economic balance of rural areas based on continuous financing is a costly process, even for the wealthy (but indebted) EU-15 countries, and faces increased political resistance from EU states. Also, this system perpetuates the adverse developments affecting the economic activity of the rural population, especially hidden unemployment and professional deactivation (for economically unviable farms, CAP transfers play a role similar to unemployment benefits, and therefore discourage the farmers from implementing any changes) (Kołodziejczak, 2018).

${ }^{2}$ Hidden unemployment is a major problem, which still needs to be solved in the course of modernization of Polish agriculture. This pertains almost exclusively to individual farms, which share in employment in the agricultural sector for at least the last twenty years has exceeded $95 \%$. Initially inefficiency of labour resources in the private sector in agriculture may have resulted from obsolete technologies and production methods. However, with time in view of the tremendous techno-logical and organizational breakthrough after 2004 in connection with the adaptation of Polish agriculture to the EU standards, excess workforce on farms was be-coming redundant not only in terms of fore, it is crucial to answer the following question: what would be the extent of occupational exclusion of the farming population in a scenario where the number agricultural employees is reduced to a level specific to European Union countries.

The purpose of this paper, formulated in the context of the above considerations, is to estimate the extent of changes in the Polish market in a scenario where the share of agricultural employees in the total number of employees would be close to that recorded in European Union countries $(5 \%)$. Such an analysis would allow to draw a picture of labor market transitions that would be required in order for the Polish agriculture to attain the labor and (per capita) income efficiency at a level close to that of European Union countries. Also, the information on the potential amount of labor resources released from agriculture allows to provide an approximate number of non-agricultural jobs that would need to be created in order to attain the target set in the simulation.

\section{METHODOLOGICAL REMARIS AND SOURCE MATERIALS}

The existence of surplus employment in agriculture means that some agricultural employees could change their job without detriment to agricultural production. Their labor is inefficient, and the absence of a gainful activity outside agriculture results in imposing an additional financial burden on agricultural households. Inefficient employment is commonly referred to as hidden unemployment. In the agricultural sector, hidden unemployment means the surpluses of agricultural labor recorded in the statistics as employees of individual farms (Frenkel 2002). Current hidden unemployment ${ }^{3}$ is determined by reference to the existing conditions of agricultural production (area structure of farms, production and

its participation in the division of income from the operations of these farms, but also because it was not involved in production processes (Kołodziejczak, 2016).

${ }^{3}$ The "current" hidden unemployment was analysed by Frenkel (2002) based on questionnaire replies provided by farm managers under the 1996 Agricultural Census. See: Frenkel (2002), Kołodziejczak and Wysocki (2015). This issue was not addressed in subsequent agricultural censuses, and therefore current unemployment may only be estimated based on surveys. For obvious reasons, the surveys are limited to small territories, and the results they provide cannot be generalized into the entire population of Polish farms. 
mechanization level, development of agricultural services, condition of the rural infrastructure etc.). In turn, potential hidden unemployment (which may become real in the future) is conditioned by labor surpluses resulting from changing conditions of agricultural production related to mechanization and technological and organizational progress; the usual consequence of the above is a considerable decrease in demand for agricultural labor (thanks to the introduction of more sophisticated, less labor-intensive production techniques and more efficient machinery) (Frenkel, 2002; Kołodziejczak and Wysocki, 2015).

This paper uses a method for estimating the level of potential hidden unemployment in agriculture based on the results of a simulated share of agricultural employees in the total population employed in the national economy. The calculations assume that $5 \%$ of the total population employed in the national economy would be employed in the agricultural sector. This share gives an approximation of the level recorded in "old" Union countries (EU-15). The $5 \%$ level enables a comparison with the economies of Spain (4.3\%), Finland (4.4\%), Ireland (4.6\%) and Austria (5.2\%) and with the UE-27 average (4.8\%) (EUROSTAT, 2018). Changes in the total employee population, in the population employed in agriculture and in the population excluded from the labor market (total of unemployed and economically inactive) were calculated; employment ratios were also estimated. When considering the creation of GDP or the generation of farmer household income, it does not actually matter whether a person is unemployed or economically inactive. Therefore, these groups are aggregated for the purposes of the simulation. Note also that it is impossible to determine whether people who lose their jobs in agriculture will be unemployed or economically inactive. As a consequence, no attempts were made to simulate the changes in the unemployment rate.

Employment and unemployment figures were retrieved from the results of the Labor Force Survey $(\mathrm{LFS})^{4}$ published by the Central Statistical Office. The

${ }^{4}$ Persons employed in individual farms include workers of agricultural holdings. In accordance with the methodology used for the 2010 Agricultural Census, this includes all persons employed in agricultural holdings, irrespective of agricultural land area and the intended purpose of agricultural production (including subsistence and semi-subsistence farms) (GUS, 2011). Because of a different classification method (which takes into account all workers and all farms, including those without calculations were based on adjusted LFS results published online at the Local Data Bank webpage of the Central Statistical Office.

The labor force released upon meeting the assumptions of this simulation would change (ceteris paribus) their economic activity status to unemployment or economic inactivity. The amount of released surplus labor may also be seen as an approximate level of demand for new jobs in the economy. In simple terms, this could be described as a situation where in order to make these changes real, the number of jobs created would need to be at least equivalent to that of jobs eliminated in the agriculture sector.

\section{RESULTS OF THE STUDY}

Table 1 presents the starting point of the simulation. Out of a total of 16,423 thousand people employed in the Polish national economy, $10.2 \%$ were agricultural employees. However, the situation varied strongly across the voivodeships, and consequently so did the distance from the 5\% level set in the simulation. The lowest share of agricultural employment (below 5\%) was recorded in Śląskie and Dolnośląskie voivodeships. These are regions with a strong mining and industrial tradition. Following the difficult economic transformation period in the 1990s, their economy became relatively modern and attractive to foreign investors. However, another factor behind such a low level of agricultural employment in these voivodeships was the fact that miners and workers exited the labor market due to restructuring of the mining and heavy industry sectors (e.g. bridge pensions or economic incentives for early retirement). The largest share of agricultural employment was recorded in south-eastern voivodeships whose economy has been largely based on agriculture for decades, and which demonstrate relatively low levels of investment: Lubelskie, Podlaskie and Świętokrzyskie voivodeships.

The employment rates varied strongly across the national territory, with the highest levels being recorded in the Wielkopolskie voivodeship (57.7\%) and Mazowieckie voivodeship $(57.6 \%)$, and the lowest ones being recorded in the Lubuskie voivodeship (51.5\%) and

marketable production), this data is not fully comparable with the results of the 2002 Agricultural Census and with Eurostat data which pertains only to workers for whom agriculture is a primary activity (Strzelecki, 2010). 
Table 1. Population employed in the national economy and in agriculture in 2017 (starting point of the simulation)

\begin{tabular}{|c|c|c|c|c|c|}
\hline Territory & $\begin{array}{l}\text { Total number of } \\
\text { persons employed } \\
\text { in Poland } \\
\text { (thousand) }\end{array}$ & $\begin{array}{l}\text { Agricultural } \\
\text { employees } \\
\text { (thousand) }\end{array}$ & $\begin{array}{l}\text { Share of agricul- } \\
\text { tural employees in } \\
\text { the total number of } \\
\text { employees } \\
(\%)\end{array}$ & $\begin{array}{l}\text { Unemployed and } \\
\text { economically } \\
\text { inactive } \\
\text { (thousand) }\end{array}$ & $\begin{array}{l}\text { Employment rate } \\
(\%)\end{array}$ \\
\hline Poland (total) & 16423 & 1672 & 10.2 & 13888 & 54.2 \\
\hline Dolnośląskie & 1234 & 56 & 4.5 & 1049 & 54.0 \\
\hline Kujawsko-Pomorskie & 862 & 112 & 13.0 & 796 & 52.0 \\
\hline Lubelskie & 867 & 197 & 22.7 & 817 & 51.5 \\
\hline Lubuskie & 429 & 35 & 8.2 & 364 & 54.1 \\
\hline Łódzkie & 1122 & 136 & 12.1 & 910 & 55.2 \\
\hline Małopolskie & 1426 & 135 & 9.5 & 1201 & 54.3 \\
\hline Mazowieckie & 2487 & 257 & 10.3 & 1830 & 57.6 \\
\hline Opolskie & 403 & 38 & 9.4 & 341 & 54.2 \\
\hline Podkarpackie & 848 & 104 & 12.3 & 781 & 52.1 \\
\hline Podlaskie & 482 & 97 & 20.1 & 425 & 53.1 \\
\hline Pomorskie & 1008 & 68 & 6.7 & 787 & 56.2 \\
\hline Śląskie & 1886 & 41 & 2.2 & 1724 & 52.2 \\
\hline Świętokrzyskie & 519 & 101 & 19.5 & 487 & 51.6 \\
\hline Warmińsko-Mazurskie & 558 & 65 & 11.6 & 542 & 50.7 \\
\hline Wielkopolskie & 1602 & 177 & 11.0 & 1175 & 57.7 \\
\hline Zachodniopomorskie & 690 & 51 & 7.4 & 651 & 51.5 \\
\hline
\end{tabular}

Source: own elaboration based on the Local Data Bank (2018).

Warmińsko-Mazurskie voivodeship (50.7\%). The first two voivodeships listed above are economically strong regions characterized by a high share of service and modern industry sectors and a strong inflow of investments. Voivodeships with the lowest levels of the employment ratio are mostly agricultural regions which attract little interest from investors. Over the past two decades, the structural burdens related to their agricultural nature have adversely affected the local populations' occupational situation, and this is still the case today.

Table 2 presents the results of a simulated reduction in agricultural employment to the level of $5 \%$ of the total population employed in the national economy. Without creating enough jobs outside agriculture, the above would result in a clear deterioration of the labor market. On a countrywide basis, 851,000 persons would need to quit their agricultural jobs, mostly in the Lubelskie voivodeship $(154,000)$, Mazowieckie voivodeship $(133,000)$ and Wielkopolskie voivodeship $(97,000)$. As a consequence, the employment rate in Poland would drop on average by 2.8 percentage points to reach $51.4 \%$; the highest decline would be experienced in the Lubelskie voivodeship (by 9.1 percentage points, to $42.4 \%$ ), Podlaskie voivodeship (by 8.0 percentage points, to $45.1 \%$ ) and Świętokrzyskie voivodeship (by 7.5 percentage points, to $44.1 \%$ ). Between the voivodeships most and least affected by the potential reduction in agricultural employment to a level of $5 \%$, there are voivodeships where the severe structural burden was reduced through the restructuring of the economy and as a result of strong economic growth, especially in the period following Poland's accession to the EU. 
Table 2. Population employed in the national economy and in agriculture, and labor force released from agriculture in 2017 (the $5 \%$ scenario)

\begin{tabular}{|c|c|c|c|c|c|}
\hline Territory & $\begin{array}{l}\text { Total number of } \\
\text { persons employed } \\
\text { in Poland } \\
\text { (thousand) }\end{array}$ & $\begin{array}{l}\text { Agricultural } \\
\text { employees } \\
\text { (thousand) }\end{array}$ & $\begin{array}{l}\text { Labor force } \\
\text { released from } \\
\text { agriculture } \\
\text { (thousand) }\end{array}$ & $\begin{array}{l}\text { Unemployed and } \\
\text { economically } \\
\text { inactive } \\
\text { (thousand) }\end{array}$ & $\begin{array}{c}\text { Employment rate } \\
(\%)\end{array}$ \\
\hline Poland (total) & 15572 & 821 & 851 & 14739 & 51.4 \\
\hline Dolnośląskie & 1240 & 62 & -6 & 1043 & 54.3 \\
\hline Kujawsko-Pomorskie & 793 & 43 & 69 & 865 & 47.8 \\
\hline Lubelskie & 713 & 43 & 154 & 971 & 42.4 \\
\hline Lubuskie & 415 & 21 & 14 & 378 & 52.4 \\
\hline Łódzkie & 1042 & 56 & 80 & 990 & 51.3 \\
\hline Małopolskie & 1362 & 71 & 64 & 1265 & 51.9 \\
\hline Mazowieckie & 2354 & 124 & 133 & 1963 & 54.5 \\
\hline Opolskie & 385 & 20 & 18 & 359 & 51.8 \\
\hline Podkarpackie & 786 & 42 & 62 & 843 & 48.3 \\
\hline Podlaskie & 409 & 24 & 73 & 498 & 45.1 \\
\hline Pomorskie & 990 & 50 & 18 & 805 & 55.2 \\
\hline Śląskie & 1939 & 94 & -53 & 1671 & 53.7 \\
\hline Świętokrzyskie & 444 & 26 & 75 & 562 & 44.1 \\
\hline Warmińsko-Mazurskie & 521 & 28 & 37 & 579 & 47.4 \\
\hline Wielkopolskie & 1505 & 80 & 97 & 1272 & 54.2 \\
\hline Zachodniopomorskie & 674 & 35 & 17 & 668 & 50.2 \\
\hline
\end{tabular}

Source: own elaboration based on Table 1 data.

That process enabled the absorption of surplus labor resources by the developing service sector, modern industry and European labor markets. However, another consequence was that a part of the working population exited the labor market, primarily including women and the elderly (Kołodziejczak, 2018).

The voivodeships (Dolnośląskie and Śląskie) where the initial level of agricultural employment was below the 5\% threshold set in the simulation would not experience any change in their situation (as no efforts would be made to increase agricultural employment, it would remain at a relatively stable level). In western and north-western voivodeships, the situation would change to a small extent. This means the Lubuskie, Pomorskie and Zachodniopomorskie voivodeships where the initial level of agricultural employment was relatively low, mainly because it had been previously reduced through the liquidation of state farms in the 1990s.

Therefore, the required reduction in agricultural employment is primarily impacted by the initial number of agricultural employees and by the share of agricultural employees in the total population employed in the national economy. However, the strength of the reduction's impact on the labor market is mainly determined by the initial level of the employment ratio which, in turn, depends primarily on the demand for labor outside agriculture (i.e. results from the economic condition of a voivodeship). Even a relatively large reduction in agricultural employment may be acceptable, provided that it has a relatively small impact on the employment ratio. However, even a moderate reduction of agricultural employment in economically disadvantaged voivodeships 
would result in a clear deterioration of the labor market, reflected by a considerable drop in the employment ratio.

The level of agricultural employment and the amount of surplus workforce in particular voivodeships suggest that structural factors continue to have a strong impact. The development and transformation processes, which differed from one voivodeship to another, played an equally important role as the legacy of the transition period. Strong differences between the characteristics under consideration also suggest that the reduction of hidden unemployment in agriculture cannot be stimulated using a unified procedure for the entire country. Nevertheless, voivodeship economies form a part of the overall national and European economy. The adverse effects of the growing number of people excluded from the labor market in voivodeships which carry the main burden of achieving the simulation targets would also impact the situation in other voivodeships and would increase the scale of international labor migration.

It may be concluded that there are no realistic ways to reduce agricultural employment if the released workforce have no alternative non-agricultural job opportunities which are conveniently located and match their qualitative characteristics. Obviously, because there is a strong temptation to initiate intervention measures, a question arises on what should be done to create such jobs. However, the author believes that the creation of jobs and the alignment of qualitative (structural) characteristics between labor supply and demand must be a natural process resulting in a sustainable balance in the labor market which does not require to be artificially maintained with public funds. The conclusion is that conditions for economic growth may be created but it does not mean stimulating economic growth in the Keynesian sense or creating jobs based on an institutional approach ${ }^{5}$. Thus, surplus labor force should be ex-

\footnotetext{
${ }^{5}$ As shown by previous research, the agricultural sector's ability to release labour force largely depends on structural factors rather than only on the number of vacant jobs (Kołodziejczak and Wysocki, 2015). This is obviously true, but in the long run, the cyclical determinants affect the structural determinants and vice versa (see Layard et al., 1991; Kołodziejczak and Wysocki, 2013). Even the best match between qualitative characteristics of supply and demand is not enough to create new jobs. Only the demand for labour, expressed by a certain number of vacant jobs, may persistently and efficiently stimulate the minimization of structural barriers. In order to hire employees, the entrepreneurs simply must experience a shortage of labour. However, an
}

tracted by non-agricultural jobs instead of being pushed out of agriculture through institutional regulations. Because labor shortages in non-agricultural sectors are increasingly common, the "extraction" process can be expected to be efficient. However, in order for this to happen, the farming population must be competitive in the labor market (must match the demand in qualitative and territorial terms) and has to be properly motivated to leave their farms. What also needs to be noted is that the modernization processes in Polish rural areas, including land concentration, are unstoppable.

\section{SUMMARY}

The purpose of this paper was to estimate the extent of changes in the Polish market in a scenario where the share of agricultural employees in the total number of employees would be close to that recorded in European Union countries $(5 \%)$. The findings and conclusions from this analysis are as follows:

1. In the study period, the level of hidden unemployment in agriculture varies from one voivodeship to another. The level of agricultural employment and the amount of surplus workforce suggest that structural factors continue to have a strong impact. The development and transformation processes, which differed from one voivodeship to another, played an equally important role as the legacy of the transition period. Strong differences between the characteristics under consideration also suggest that the reduction of hidden unemployment in agriculture cannot be stimulated using a unified procedure for different voivodeships.

2. It may be concluded that there are no realistic ways to reduce agricultural employment if the released workforce have no alternative non-agricultural job opportunities which are conveniently located and match

artificial and excessive regulation of that process can be harmful and may give rise to pathological phenomena (e.g. dismissing those already employed in order to access subsidies for hiring people assigned by employment authorities). In a broader context, the question must also be asked as to the ultimate source of financing for these measures and whether this type of interventionism provides macroeconomic benefits, especially considering the fact that it generates additional demand for public funds. While the author does not deny the general purposefulness of interventions, he indicates that the measures in place are often inconsistent with each other and inefficient at a macroeconomic level. See also: Tyrowicz (2011). 
their qualitative characteristics. However, the 5\% level used in the simulation seems attainable within a ten to twenty-year time frame, mainly because of the persistent economic growth and a shortage of labor experienced in non-agricultural sectors. However, in order for this to happen, the farming population must be competitive in the labor market (must match the demand in qualitative and territorial terms) and must have an adequate economic incentive to leave their farms.

3. The author believes that the creation of jobs and the alignment of qualitative (structural) characteristics between labor supply and demand must be a natural process resulting in a sustainable balance in the labor market which does not require to be artificially maintained with public funds. The conclusion is that conditions for sustained economic growth may be created but it does not mean stimulating economic growth in the Keynesian sense or creating jobs based on an institutional approach.

\section{SOURCE OF FINANCING}

This paper is funded by the National Science Centre of Poland within the MINIATURA research project No. NCN DEC-2017/01/X/HS4/00565 "Determinants of Economic Activity of the Rural Population in Poland. Opportunities to reduce hidden unemployment in agriculture" (Determinanty aktywności ekonomicznej ludności wiejskiej w Polsce. Możliwości redukcji bezrobocia ukrytego w rolnictwie).

\section{REFERENCES}

Czyżewski, B. (2012). Produktywność zasobów w rolnictwie w Polsce wobec paradygmatu zrównoważonego rozwoju [Resource productivity in Polish agriculture in the context of the sustainable development paradigm]. Stud. Ekon., 2(LXXIII), 165-188.

EUROSTAT (2018). Retrieved July 15th 2018 from: https:// ec.europa.eu/eurostat

Frenkel, I. (2002). Przemiany ludnościowe w gospodarstwach domowych rolników indywidualnych w latach 1996-2000 [Population changes in households of individual farmers in 1996-2000]. Wieś Roln., 3, 52-59.

Floriańczyk, Z. (2009). W świetle rachunków ekonomicznych [In the context of economic accounts]. Nowe Życie Gosp., 23-24, 14-15.
GUS (2011). Raport z wyników. Powszechny Spis Rolny 2010 [Report on results. General Agricultural Census 2010]. Retrieved July 15th 2018 from: https://danepubliczne.gov.pl

Kołodziejczak W. (2016). Nadwyżka zatrudnienia w polskim rolnictwie - projekcja na tle państw Unii Europejskiej [Surplus of employment in Polish agriculture - projection against the background of European Union countries]. Zesz. Nauk. SGGW Warsz. Probl. Roln. Świat., 16(31), 1, 129-141.

Kołodziejczak, W. (2018). Labour force in Polish rural areas after Poland's accession to the European Union. Proceedings of the 2018 International Conference "Economic Science For Rural Development”. No 47 Jelgava, LLU ESAF, 911 May 2018, DOI 10.22616/ESRD.2018.000

Kołodziejczak, W., Wysocki, F. (2013). Identyfikacja charakteru bezrobocia w Polsce w latach 2006-2009 [The nature of unemployment in Poland in 2006-2009]. Gosp. Narod., 9(265), 29-52.

Kołodziejczak, W., Wysocki, F. (2015). Determinanty aktywności ekonomicznej ludności wiejskiej w Polsce [Determinants of economic activity of the rural population in Poland]. Poznań: Wyd. UP w Poznaniu.

Layard, R., Nickell, S., Jackman, R. (1991). Unemployment. Macroeconomics Performance and the Labour Market. Oxford-New York: Oxford University Press.

Local Data Bank (2018). Retrieved July $10^{\text {th }} 2018$ from: http:// stat.gov.pl

Polska wieś 2018. Raport o stanie wsi [Rural Poland 2018. Rural Development Report] (2018). Warszawa: Fundacja na rzecz Rozwoju Polskiego Rolnictwa, Wydawnictwo Naukowe Scholar.

Rembisz, W. (2016). Relacje wynagrodzenia i wydajności czynnika pracy w rolnictwie na tle gospodarki narodowej i jej sektorów w Polsce w okresie 2005-2012 [Relationship between remunerations and labour productivity in agriculture compared to the Polish national economy and its sectors in 2005-2012]. Wieś Roln., 2(171), 41-58.

Strzelecki, P. (2010). Projekcja liczby pracujących w rolnictwie indywidualnym $w$ Polsce $w$ latach 2008-2035 [Projection of the number of persons employed in private farming in Poland in 2008-2035]. Zesz. Nauk. Inst. Stat. Demogr. SGH, 6.

Tyrowicz, J. (2011). Histereza bezrobocia w Polsce [Hysteresis of unemployment in Poland]. Warszawa: Wyd. UW. 